\title{
Libya: When Cities Contribute to Building the Foundations for Stability and Growth, in Partnership with European Local and Regional Authorities
}

\author{
Filippo Terruso \\ EU's Committee of the Regions, Brussels, Belgium
}

Email address:

terruso@skynet.be

To cite this article:

Filippo Terruso. Libya: When Cities Contribute to Building the Foundations for Stability and Growth, in Partnership with European Local and Regional Authorities. Advances in Sciences and Humanities. Vol. 3, No. 4, 2017, pp. 31-34. doi: 10.11648/j.ash.20170304.11

Received: July 5, 2017; Accepted: July 14, 2017; Published: August 9, 2017

\begin{abstract}
Local and regional authorities (LRAs) work to strengthen cross-border cooperation or relations with counterparts of third countries with a view to open up to new opportunities for economic, social or political development. Stability in a given geographical area affected by political turmoil can push LRAs to intervene in order to offer to classical diplomacy new and complementary channels for communication. This implies capacity actions buildings where rule of law, democracy, human rights, transparency, fight corruption are tackled. In addition, capacity building is instrumental to service delivery, led by LRAs in order to provide better conditions and future perspective to citizens. Elected mayors can promote better governance at the local level and insofar strengthening the concept of local democracy, which is also connected with the consolidation of institutions in post-conflict areas. The exchange of good practices and excellences in different fields of intervention for LRAs is one of the instruments of city-diplomacy. The case of the cooperation set up by EU's and Libyan local authorities is a good example for understanding the potential help coming from sub-national level in particular when the formal diplomacy hampers national or international cooperation to properly act. Through the networking with Libyan mayors set up by the EU's Committee of the Regions - the institution representing regional actors and mayors within the EU - Libyan mayors cooperate internally and with new partners in Europe.
\end{abstract}

Keywords: Local and Regional Authorities, City Diplomacy, Libya, Territorial Cooperation

\section{Introduction}

The concepts of city diplomacy and decentralized cooperation involve regional and local authorities in international relations and in development cooperation, and are used mostly when traditional diplomacy and cooperation fail to take their natural course through the official routes and channels of multilateral dialogue (international organizations). Unlike in the case of non-governmental organizations, the involvement of institutional players, such as mayors or regional elected officials, gives proximity to diplomacy, a political and official make-up that allows otherwise silent players to move, activate and open fora for discussion in the international stage. This process allows creating new opportunities for cross-border and international dialogue, business-oriented partnerships and confidencebuilding instruments for local or regional authorities.
The added value of post-conflict, peace-building talks and the rebuilding of trust between the players involved in a given country is further enhanced when capacity-building measures or tailored projects accompany political talks, directly involving local authorities which are by nature most familiar with citizens' needs and they are responsible - in particular in national contexts already affected by war or often acute social crises - for finding the most sustainable solutions to daily problems that may degenerate into further social crises or radicalism, if not timely addressed. The possibility of assisting local authorities in re-establishing the necessary confidence of citizens in their governing bodies, through the provision of services of general interest and as a stimulus for job creation at local level, is of extreme interest for the community as a whole and therefore for the respective country and the international community, and more broadly for the possible stabilization that can be achieved in a 
complex context.

The advantage of cooperation through partnerships working at local or regional levels, lies in the permeability and flexibility of their working methods and their political implication, that are specific to non-conventional players, but who nevertheless are strong in the legitimacy conferred on them by the role they hold (in particular when holding direct electoral mandate; in the Libyan case, the only active after the end of the parliamentary term). A mayor may therefore consider it appropriate to take international action to develop an economic, social and political partnership with another mayor beyond routine political relations between the respective countries of origin. Similarly, a mayor or a regional actor may autonomously consider it appropriate to establish relations with a given international institution, provided that the given institution remains open to nonconventional actors, meaning going beyond the standard relationship with national governments. Recently, the need to take direct positioning in external affairs has also been justified by the rise of migration towards European or MENA region area, and this to both prepare local authorities in receiving migrants or asylum seekers, implement integration policies, starting schemes for circular migration which imply vocational training before the migrants' departure towards a given region or city.

The ability to raise and use funds to carry out specific projects on the ground, in addition to the more technical aspects linked to capacity-building (from public administration to the management of local or regional authorities' typical services such as water, waste disposal, the contribution of primary emergency health assistance, public safety, social policies - including the fight against radicalization, economic policies generating employment at the local level and the territory's sustainable development) remains the litmus test of these "proximity diplomacy" actions that should be able to rely on a budget that can be spent in the short term for them to be useful. Small actions and interventions intended to resolve everyday problems, most often left behind owing to force majeure situations in conflicts - although of obvious interest to the community often fall by the wayside with international cooperation bodies because they are too small to be financed and monitored by institutions geared to the classical development cooperation policy, from the United Nations to the international financial bodies and to the European Union, tending to follow macroeconomic logic or dictated by administrative requirements of economies of scale, necessity or contingent political convenience. This implies that projects which are small in scale but extremely urgent in an alreadyweakened community are often not even proposed to the various national or European contexts, despite the appeals of the local and regional bodies concerned. In addition, the policy of the EU to externalize to implementing agencies (ranging from NGOs to national cooperation agencies, from civil society to ministries of foreign affairs and UN's agencies) the administration of their funds for cooperation, from the planning and the monitoring, has converted the EU's
General Directorates into a aseptic body often lacking of the needed political knowledge of the specificity of a given region of intervention, and has obliged final users to run after a chain of "Chinese boxes" to detect where funds are and who is responsible for it. The subcontracting method implies the full involvement of national levels which can cause abortion of cooperation tailored by local authorities.

\section{The Case of Libya}

The case of post-dictatorship and post-civil war in Libya is emblematic in this context: a country where the national system imploded is not in a position to become the natural partner of international players, that are still predominantly based on relations through official channels, is looking at pragmatically substitutes a vacuum of power by applying by default the principle of subsidiarity and decentralization. Still, international partners keep asking Libya to implement traditional schemes and put forward national interlocutors to talk to, which do not always exist in real life or apply in given circumstances and regional areas. The European Union, by its very nature and albeit with cumbersome limitations, could, however, be in a position to provide alternative political entities (mayors and regional representatives) that can act internationally, beyond Member States and conventional diplomacy. The EU recognizes indeed, not just in its institutional setting, a place for regional and local authorities to work together and express its own views (the Committee of the Regions is the institution set by the Maastricht treaty to represent regional and local authorities of the Member States within the EU institutional framework), but also recognizes to regional and local actors a role in implementing specific policies - through the principle of partnership inspired by the principle of subsidiarity - such as cohesion and regional policy and rural development (by themselves covering half of the EU budget).

Unfortunately, in the context of the international cooperation if this is promoted for talks and for capacity building exercises, it is still not properly working when it comes to consider local players as actors allowed to manage financial aid as official counterparts in programs such as the Cross Border Cooperation Mediterranean. The latest is indeed managed by regional actors within the EU but it remains in the hands of national authorities in the southern or eastern rims of the Mediterranean. For the Libyan case the situation is even more complexed due to the complexity of the role of the government of national agreement sponsored by the United Nations and which lacks of recognition at (national and) international scale: this hampers once more Libyan mayors to benefit from the funds put at disposal by the EU to local authorities and it shows how inflexible the EU's administration is when it comes to deal with external bodies.

Despite the rigidity concerning the financial aspects, and specifically in the search for interlocutors with a view to implement the agreements reached to put an end to the civil war in Libya and in order to rebuild a unified and functional national governance system, the European Union has 
nevertheless opened the doors to players on the ground, following the UN and its search of national agreement over the Skhirat political agreement. Within that context and in the framework of the already established ARLEM (Assembly of regional and local authorities in the Mediterranean), the European regional and local authorities have thus created a new partnership with their respective mayors in Libya. In concert with the European Commission and its external service (EEAS), an alternative model for dialogue, strongly anchored in a bottom-up approach and attentive to the realities of the different communities and the local needs for territorial development, has been therefore developed since 2015 .

Starting from the dialogue between the different Libyan communities, already promoted by the United Nations in the implementation of the peace process in 2015, growing confidence in the new partners for constructive dialogue was proposed to the Libyan mayors by the CoR: this was also possible by grounding the new dialogue to the Libyan Law No. 59 of 2012, concerning the Local Administration System, and which gave a new repartition of competence based on the principle of subsidiarity and decentralization. The process of decentralization was halted in Libya since 2014, leaving a vacuum on the final vision of nature and mandates of the national system of local governance; despite this, mayors and city councilors are still working in the interest of citizens, though lacking of adequate financial means and an inevitable lack of coherent coordination with the national level. Willing to work with new European partners, mayors and regional representatives, has also helped the mayors to consolidate their own internal dialogue, which would otherwise have been impossible. The joint search for practical solutions to similar or comparable problems has lead, then, to the creation of the CoR's multilateral decentralized cooperation initiative ("Nicosia Initiative for Libyan Local Authorities"). The Libyan mayors, invited to attend ARLEM meetings as Observers, have acted pragmatically in creating a network of 'focal points', one for each city council involved, composed of representatives and specialists who promptly intervene to deal with matters within their area of competence of a given action promoted by the Nicosia Initiative. As for the CoR, it has selected from among its own Members the best practices in areas of interest for the Libyan partners and has raised the European Commission's awareness with regard to specific needs emerging by the partnerships.

The Initiative allows match-making between European and Libyan mayors and consequently organizes technical workshops held in the various European pilot cities in the identified field of operation. The positive response of the European Commission and of the EU's External Action Service has enabled Libyan local elected politicians and their specialists to come to Europe meeting their European colleagues and visit: water managements systems and waste water treatment (Murcia region in Spain), and waste facilities plants (Antwerp in Belgium), primary health assistance centres (San Antonio Real in Portugal), public administration centres, human resource management and accountability
(Nicosia in Cyprus), municipal budget and transparency offices (Flanders region in Belgium), fishery sector bodies (Friuli Venezia Giulia region in Italy), and the innovative methods to prevent the radicalization of young people in cooperation with Unicef and the Institute for Economic and Peace. Libyan specialists have thus begun to talk with their European colleagues, designing specific projects for their respective communities, including continuous learning programs for public administration, which is still in the planning stage, but which should allow to training Libyan local civil servants within Libyan universities developing the curricula in direct cooperation with the municipalities.

The identified projects in different fields should be implemented in order to concretely show to the citizens the added value of these decentralized partnerships. The ability of Libyan local elected representatives to find new partners in Europe that are interested in the Libyan market and society shall be understood by Libyans as a positive element and it should be seen as good example for the consolidation of the local government system in the country. To date, more than 100 representatives of Libyan municipalities have enjoyed the first match-making of the Nicosia Initiative from 2016 and 2017 and local actors are ready to make the most of the new partnerships set around the EU's local and regional authorities.

\section{The Partnership with the European Union's Committee of the Regions}

The initiative taken by the CoR and which was conceived as part of its work with the regional and local authorities of Mediterranean neighborhood countries that work together through ARLEM has offered a working method that originated in the desire to pool and share best practices in local communities' fields of local governance. ARLEM is the platform body run by the CoR within the Union for the Mediterranean imagined as its "territorial pillar", a political consultative assembly devoted to the dialogue between local authorities of the 3 shores of the Mediterranean basin, a unique body allowing sub-national authorities to be heard in a multi-lateral framework by national government and the EU. The CoR has chosen to work with Libya specifically because Libya represents a natural geographical partner that would otherwise be condemned to a new international isolation which could undermine stability in the whole of the Mediterranean. The present volatility of the Libyan context, which could become a platform for international criminal trafficking, with obvious repercussions on the flow of migration from North Africa, the Middle East and Europe, as well as a catalyst for fundamentalism and the radicalization of young people, is a matter which European partners are deeply concerned about, particularly in the absence of timely answers from international bodies and diplomacy - answers that local partners are calling for.

Despite the internal rivalries and different political affiliations as well as sensitive economic and power sharing conflicts raised fter the end of the Gaddafi regime, a number 
of mayoralties (Tripoli, Zintan, Garyan, Sebbah, Tobruk, Sirte and Benghazi) have to date decided to work together to make themselves better heard in Europe and to boost their opportunities to meet new partners. They have set aside differences by overcoming the national political chaos in order to address urgent needs of their role and the pressing needs of their respective communities who have elected them: a gesture of exceptional political maturity for these very young local democracies bodies. Basically, the CoR has considered an advantage to open a new channel of communication with Libyan potential partners, being the elected mayors having a mandate to operate at the service of the citizens, to assure better conditions of life, creating job opportunities and insofar contributing to the effort to stability and de-escalation.

The Initiative could go beyond the match-making and the project-drafting phase: the implementation on the ground of small-scaled projects based on locally identified strategic needs of paramount importance for citizens and for the new Libyan local democratic structures. By setting a system of cooperation (based on the concept of peer-to-peer cooperation and exchange) promoting small height-impact oriented projects, which could be exported also in other countries of the European Neighborhood Policy, the CoR proposes a partnership building approach where the main actors are local and not national entities. Ideally, the platform should remain open to all EU's cities and regions interested in sharing best practices and offering in-kind or financial support and at the same time it should be open to all Libyan local authorities having the capacity of engaging in new partnerships, possible through the involvement of a national association of local authorities which is currently under construction in Libya.

\section{Conclusions}

The model proposed by the Nicosia Initiative for Libyan local Authorities is a first step towards improving and further strengthening a cooperation approach based on peer-to-peer exchanges that could replicate in other MENA countries and in the context of the EU's Eastern Partnership, with the ambition to become a format for direct financing of small-scale and people-to-people projects. Beside existing financial and cooperation mechanisms that often prove to be too slow to operate in a quickly chaining and fragment political environment, it is worth also investing in a bottom-up approach by granting support to decentralized partners, starting from cross-border cooperation, that allows both for flexibility and speedy implementation. The challenging experiences of Libyan and European mayors and regional actors should encourage exploring complementary ways of cooperation through making a better use of the wide experience and wealth of territorial partners. Donors would consider a new prism at their working methods where local governance has little freedom to move in the international arena, starting in the field of territorial cooperation, if not accompanied and sponsored by national structures; similarly, small-scale and people-to-people projects should be encouraged and implemented by structures of proximity, at the local and regional levels, while for the time being they are too often considered as an administrative burden by the main actors of the international cooperation.

The CoR provides a good entry point to the European local and regional authorities (about 700 of them represented in the $\mathrm{CoR}$ ) and a privileged access to the main institutions of the EU, including financial institutes where to pitch financial assistance for the Libyan mayors. The CoR is indeed providing an institutional dimension to the initiative as well as a political backing from local and regional politicians acting in Brussels on behalf of their democratic institutions. Against the analysis carried by the UNDP, where it was stressed the lack of a vision for local governance, institutional capacities and resources, limited managerial and administrative capacities, absence of reliable needs assessments methods, local targets and quality standards, lack of efficient organizational structures for service provision, European and Libyan local authorities have chosen to react through the window of opportunity given by the EU's CoR and promote partnership in the most pressing fields where municipalities need help, ie: project management skills; human resources (planning, recruitment, training polices); strategic planning; financial management; public service delivery (with particular focus on water and waste management); municipal management in times of crisis.

The exercise could help Libyan local authorities to me more present in the international arena where funds are given not only for cooperation and social and economic development, but also for achieving major horizontal targets (COP 22 and follow-up; fight radicalization; fight smuggling of human beings). In addition, Libyan local authorities should improve their financial management and application of anti-corruption measures; the delivery of public services; promote measures for territorial development including jobcreation; the reinforcement of cohesion and resilience of Libyan local communities through targeted training in peacebuilding aiming in particular at Libyan youth.

\section{References}

[1] Van der Pluijm, R (2007). City Diplomacy: the expanding role of cities $\mathrm{n}$ international policies; The Hague, Clingendael Institute of international relations.

[2] Terruso, F (2017) Complementing traditional diplomacy; regional and local authorities going international, European View, November 2016, Springerlink open access.

[3] UNDP, Rapid diagnostic of the situation of local governance and local development in Libya, November 2015.

[4] CoR Nicosia Initiative on: https://t.co/GZIgEWtlzQ.

[5] CoR opinion (Civex VI/023 - 2017) on "Migration on the central Mediterranean route - managing flows, saving lives".

[6] CoR opinion (Coter VI/023 - 2017) on "People-to-people and small scaled projects in cross-border cooperation programs".

[7] CoR opinion (Relex IV-016 - 2009) on "City Diplomacy". 